\title{
アファチニブ(ジオトリプ ${ }^{\circledR}$ 錠 $20 \mathrm{mg} / 30 \mathrm{mg} / 40 \mathrm{mg} / 50 \mathrm{mg}$ ) の薬理学的特徵および臨床試験成績
}

\author{
高橋 希 ${ }^{1}$, 鈴木 忍 $^{2)}$, 酒井 兼司 ${ }^{2)}$, 東 久弥 ${ }^{1)}$
}

要約 : 近年, 上皮成長因子受容体 $(E G F R)$ 遺伝子変 異陽性の進行・再発非小細胞肺がん（NSCLC）に対す る 1 次治療において, EGFR-チロシンキナーゼ阻害薬 (TKI）の有効性が示されている.アファチニブは, EGFR (ErbB1) のほか, HER2 (ErbB2) やErbB4の チロシンキナーゼ領域のアデノシン三リン酸 (ATP) 結合部位に共有結合することで, それらのリン酸化を 阻害する不可逆的 ErbB 受容体ファミリー阻害薬であ る. 非臨床研究においてアファチニブは, EGFRのほ か, HER2 および ErbB4 のチロシンキナーゼ活性を選 択的かつ持続的に阻害し, EGFR受容体を発現する 種々の腫瘍細胞に対する細胞増殖抑制効果およびマウ ス担がんモデルに対する腫瘍増殖抑制効果を示した.

国内外で実施された EGFR-TKI を含む化学療法未治療 の $E G F R$ 遺伝子変異を有する進行 NSCLC 患者を対象 とした臨床試験では, アファチニブは標準化学療法に 比べ，無増悪生存期間（PFS）の有意な延長を示した ほか, 健康関連の生活の質（QOL）の評価において, 肺がん関連症状の改善効果を示した.アファチニブに よる有害事象としては, 主に下痢, 発疹／ざ瘡, 口内 炎，爪の異常などが認められたが，その多くは支持療 法, 休薬／減量により管理可能であった. 以上から, アファチニブの有効性, 安全性が確認されたことによ り, 我が国では, 2014 年 1 月に「EGFR 遺伝子変異陽 性の手術不能又は再発非小細胞肺癌」に対する治療薬 として承認された。

\section{1. はじめに}

近年, 進行・再発非小細胞肺がん（NSCLC）に対し
ては, 全身状態や年齢, 組織型に加え, driver mutation の状態によって治療が選択・決定されるようになり, バイオマーカーを用いた個別化による分子標的治療の 実践が求められるようになった。 上皮成長因子受容体 $(E G F R)$ 遺伝子変異陽性の進行・再発 NSCLC では, これまでの臨床試験（WJTOG3405 試験, NEJ002 試験, OPTIMAL 試験, EURTAC 試験）において，プラチナ 製剂併用療法に対する EGFR-TKI の有効性が示されて いることから (1-4), 多くの場合 EGFR-TKI が 1 次治 療で使用されている。 また, 『肺癌診療ガイドライン』 (日本肺癌学会編) では, IV 期 NSCLCの 1 次治療にお いて, 組織学的サブタイプが非扁平上皮がんの $E G F R$ 遺伝子変異陽性症例に対し, EGFR-TKIによる治療が 推奨されている(5).

アファチニブは, 可逆的な EGFR-TKI であるゲフィ チニブ，エルロチニブと異なり，EGFRのチロシンキ ナーゼ領域のアデノシン三リン酸 (ATP) 結合部位に 共有結合することにより, EGFRのリン酸化を不可逆 的に阻害する $(6)$. また, EGFR (ErbB1) と同様に ErbB 受容体ファミリーに属する HER2（ErbB2）なら びに ErbB4についても細胞内チロシンキナーゼ領域 におけるATP結合部位に共有結合することにより，そ れらのリン酸化を選択的に阻害する ErbB 受容体ファ ミリー阻害薬である $(6,7)$ （図 1). 非臨床研究におい て, エクソン 19 の欠失変異（Del 19）またはエクソン 21 の L858R 点突然変異 (L858R) の EGFR 遺伝子変異 を有する NSCLC 細胞モデルがアファチニブに対して 特に高い感受性を示すことや, アファチニブが ErbB 経路に調節異常のある疾患動物モデルの ErbB 受容体

キーワード：アファチニブ，ジオトリプ ${ }^{\circledR}$, 上皮成長因子受容体 (EGFR)，チロシンキナーゼ阻害薬（TKI），

非小細胞肺がん（NSCLC）

${ }^{1)}$ 日本ベーリンガーインゲルハイム株式会社 医薬開発本部クリニカルデイベロップメント\&メディカルアフェアーズオンコ ロジー領域（†141-6017 東京都品川区大崎 2-1-1 ThinkPark Tower）

2) 日本ベーリンガーインゲルハイム株式会社 神戸医薬研究所 薬物動態安全性研究部

（ テ650-0047 兵庫県神戸市中央区港島南町 6-7-5）

E-mail: nozomu.takahashi@boehringer-ingelheim.com 原稿受領日：2014 年 11 月 14 日, 依頼原稿

Title: Pharmacological and clinical profile of afatinib (Giotrif ${ }^{\circledR}$ )

Author: Nozomu Takahashi, Shinobu Suzuki, Kenji Sakai, Hisaya Azuma 


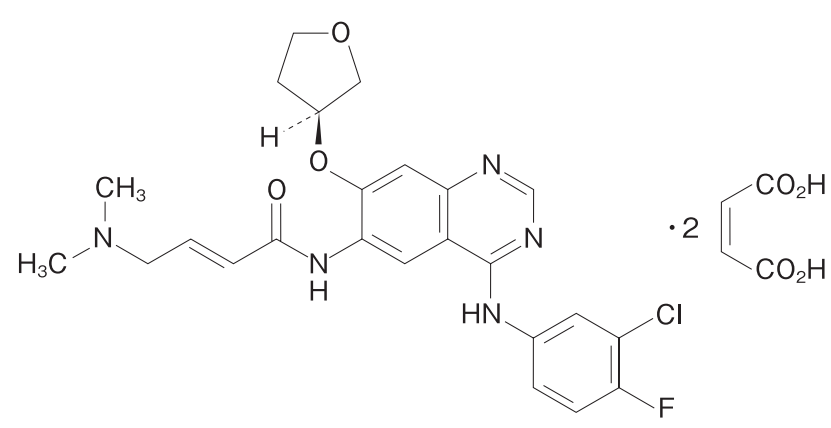

図 1 アファチニブマレイン酸塩の化学構造式（文献 7 より引用）

シグナルを効果的に阻害し, 腫瘍増殖阻害および腫瘍 縮小の効果を示すことが確認されている.

$E G F R$ 遺伝子変異陽性の進行・再発 NSCLCに対す るアファチニブの抗腫瘍効果や転移・進行の抑制を期 待し, 国内外で臨床開発が進められてきた。 アファチ ニブは，2014 年 1 月までに米国，EUをはじめとする 40 以上の国と地域で $E G F R$ 遺伝子変異陽性の進行 · 再発 NSCLC（国・地域で承認内容は異なる）に対する 治療薬として承認されている。我が国に招いても 2014 年 1 月に「EGFR 遺伝子変異陽性の手術不能又は 再発非小細胞肺癌」に対する治療薬として承認され, 同年 5 月よりジオトリ $>^{\circledR}{ }^{\circledR}$ 錠 $20 \mathrm{mg} / 30 \mathrm{mg} / 40 \mathrm{mg} / 50 \mathrm{mg}$ として発売が開始された。用法・用量は, 「通常, 成人 にはアファチニブとして 1 日 1 回 $40 \mathrm{mg}$ を空腹時に 経口投与する。なお，患者の状態により適宜増減する が, 1 日 1 回 $50 \mathrm{mg}$ まで増量できる.」とされた. 本稿 では, アファチニブの薬理学的特徵, および EGFR 遺 伝子変異陽性の進行・再発 NSCLCに対する臨床試験 成績を紹介する。

\section{2. アファチニブの薬理作用}

\section{1）各種キナーゼに対する阻害作用および選択性}

がん細胞中に過剩発現していると推定される ErbB 受容体ファミリーは, EGFR, HER2, ErbB3 おょび ErbB4 からなり, 細胞膜上でへテロ二量体およびホモ 二量体を形成し, がん細胞増殖, 血管新生, アポトー シスの抑制，浸潤・転移に関与することが知られてい る.アファチニブは, ヒト組換えプロテインキナーゼ ドメインを用いた酵素アッセイにおいて，EGFRのほ か, HER2 および ErbB4 のチロシンキナーゼ活性を阻 害することが示された（6）（表 1).

\section{2）不可逆的結合による EGFR 阻害作用}

ゲフィチニブ，エルロチニブは細胞内のチロシンキ ナーゼ領域にATP と競合的に結合するのに対して, ア ファチニブは ATP 結合部位の 797 位システイン残基
表 1 分子キナーゼアッセイにおけるアファチニブの阻害作用およ び選択性

\begin{tabular}{|l|l|}
\hline キナーゼ & アファチニブ $\mathrm{IC}_{50}[\mathrm{nM}]$ \\
\hline EGFR (HER1, ErbB1) & $0.465,0.230$ \\
\hline HER2 (ErbB2) & $13.8,28.3$ \\
\hline HER4 (ErbB4) & $1.15 \pm 0.24(4)$ \\
\hline BIRK & $>100000$ \\
\hline c-src & $>4000$ \\
\hline Lck & 1720,1990 \\
\hline Lyn & $1527 \pm 154(4)$ \\
\hline VEGFR-2 & $>100000$ \\
\hline HGFR & 13000 \\
\hline
\end{tabular}

個々值 $(\mathrm{n}=1$ または 2$)$, 平均值 \pm S.E.M. $(\mathrm{n}=4)$, 括弧内は例数を 示す.

[受容体チロシンキナーゼ］ BIRK：ベータインスリン受容体キナー ゼ, VEGFR-2：血管内皮増殖因子受容体 2, HGFR：肝細胞増殖因 子受容体.

[非受容体型チロシンキナーゼ］c-src：ラウス肉腫ウイルスの形質 転換遺伝子のがん原遺伝子, Lck：リンパ球特異的プロテインチロ シンキナーゼ, Lyn：LCK/YES 関連チロシンキナーゼ。（文献 6 よ り引用・改変)

に共有結合する (不可逆的結合) (6)。そのため, ア ファチニブは薬剤濃度が阻害濃度未満に低下した後も, 持続的にチロシンキナーゼ領域のリン酸化を阻害する と考えられる. EGFRを過剩発現しているヒト外陰部 扁平上皮がん細胞株（A431）を用いて，アファチニブ を 1 時間曝露してから洗浄処理を行ったところ, 洗浄 後 8 時間経過してもアファチニブによるEGFRリン酸 化阻害作用が持続することが確認された(6)（図 2).

なお，本検討で比較に用いた canertinib は研究用試薬 で, 不可逆的な ErbB 受容体ファミリー阻害薬である.

3) 抗腫瘍効果

ErbB 受容体を発現する種々の腫瘍細胞において, アファチニブは ErbB 受容体の活性化を阻害し, 細胞 増殖抑制効果を示した(6). また，マウス担がんモデ ルに拈いても，アファチニブは腫瘍増殖抑制効果を示 した (6). L $858 \mathrm{R} / \mathrm{T} 790 \mathrm{M}$ 変異を有する $\mathrm{EGFR}^{\mathrm{L} 858 \mathrm{R} / \mathrm{T} 790 \mathrm{M}}$ を発現した NSCLC 細胞株（NCI-H1975）のヌードマ ウス担がんモデルを用いた検討では，アファチニブ $15 \mathrm{mg} / \mathrm{kg}\left(45 \mathrm{mg} / \mathrm{m}^{2}\right)$, および $20 \mathrm{mg} / \mathrm{kg}\left(60 \mathrm{mg} / \mathrm{m}^{2}\right)$ の 20 日間連日経口投与で腫瘍の退縮が認められ, 薬 物処置群 ( $\mathrm{T}$ ) と溶媒処置群 (C) の腫瘍体積比 ( $\mathrm{T} / \mathrm{C}$ 比）はそれぞれ $18 \%$ と $12 \%$ であった(8).

\section{3. 臨床試験成績}

以上の薬理学的特徵を踏まえて, $E G F R$ 遺伝子変異 を有する EGFR-TKI 未治療の進行・再発 NSCLC 患者 (以下, EGFR-TKI 未治療例) や, 細胞傷害性化学療法 および可逆的 EGFR-TKIによる治療後に不応となった 
0 時間

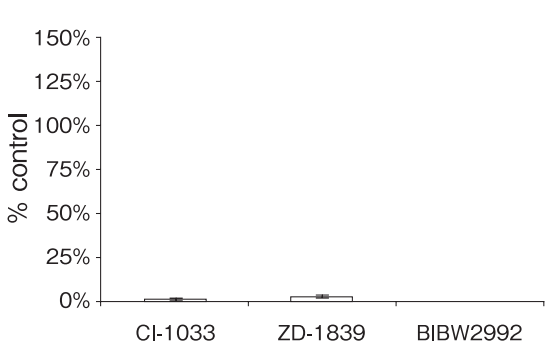

24 時間

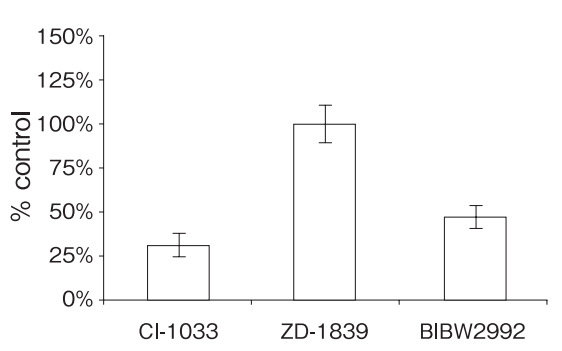

8 時間

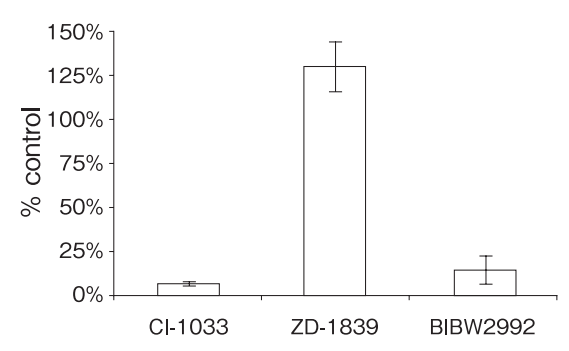

48 時間

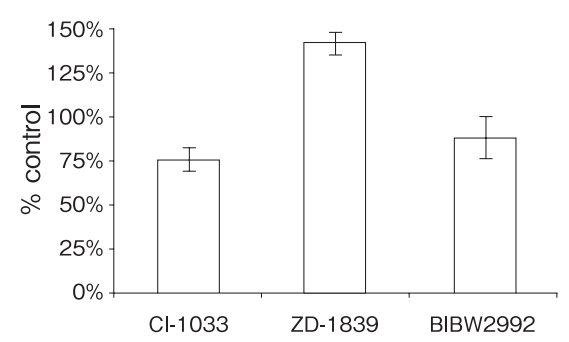

図 2 薬剤洗浄後の細胞における EGFR リン酸化阻害作用の持続

EGF $(100 \mathrm{ng} / \mathrm{mL})$ に誘発された EGFR リン酸化を示す. $80 \mathrm{nM}$ の canertinib (Cl-1033), ゲフィチニブ (ZD-1839) およびアファチニブ (BIBW 2992) を 1 時間前処理し，その後2，4，8，および24 時間に洗浄処理を行った. 薬凧の前処理終了後 $0,8,24$ および 48 時間に EGFR リン酸化を測定し, 対照に対する\%として表した. 平均值士S.D. ( $N=5 \sim 6)$. (文献 6 より引用・改变)

進行・再発 NSCLC 患者（以下，EGFR-TKI 既治療例） に対する検討が行われた。

\section{1）最大耐量}

海外での悪性固形がん患者 53 例を対象にアファチ ニブ 10，20，30，40，50 mg/日を 1 日 1 回連日経口投 与した多施設共同非盲検非対照用量漸増試験である第 I 相臨床試験において, 第 1 サイクル (dayl〜28) に 用量制限毒性（DLT）が 3 例発現した。 その内訳は $30 \mathrm{mg}$ / 日投与群の呼吸障害 1 例, $40 \mathrm{mg}$ / 日投与群の 発疹 1 例, $50 \mathrm{mg}$ /日投与群のざ瘡様皮虐炎 1 例であっ たことから,アファチニブの最大耐量（MTD）を $50 \mathrm{mg}$ /日と決定し, 第 II 相試験以降の推奨用量 - 用法 とされた(9)。また，日本人 NSCLC患者においても， 次項に示す国内第 I / II 相臨床試験（LUX-Lung 4）の 第 I 相パートにて, 第 1 サイクル (dayl〜28) での DLT 発現が $50 \mathrm{mg} /$ 日投与群 6 例のうち, 粘膜炎 1 例 のみであったことから, アファチニブの MTD は $50 \mathrm{mg} /$ 日と決定され, 第 II 相試験以降の推奨用量 ・用 法とされた (10).

\section{2) 臨床薬物動態}

化学療法（プラチナ製郕および／またはゲフェチニ ブ／エルロチニブなど）の治療歴のある日本人進行 NSCLC 患者 12 例に, アファチニブ $20 \mathrm{mg}$ /日（3 例), $40 \mathrm{mg}$ /日（3 例）, $50 \mathrm{mg} /$ 日（6例）を 1 日 1 回空腹時
反復投与した国内第 I / II 相臨床試験（LUX-Lung 4） の第 I 相パートの用量漸増非盲検試験において, ア ファチニブの最高血漿中濃度到達時間 $\left(\mathrm{t}_{\max }\right)$ および 定常状態の最高血漿中濃度到達時間 $\left(\mathrm{t}_{\mathrm{max}, \mathrm{ss}}\right)$ の中央値 は 3〜4 時間であり, 定常状態における終末相半減期 の幾何平均值は 33.5 40.4 時間であった (10). みかけ の全身クリアランス抢よびみかけの分布容積は高 く, 累積係数は最高血中濃度 $\left(\mathrm{C}_{\max }\right)$ で $1.96 \sim 3.97$ $\left(\mathrm{R}_{\mathrm{A}, \mathrm{C} \text { max }}\right)$, 血中濃度 - 時間曲線下面積 (AUC) で 1.63 $4.41\left(\mathrm{R}_{\mathrm{A}, \mathrm{AUC}}\right)$ で, 投与開始から 7 日後の day8 には定 常状態に達したと考えられ, トラフ血漿中濃度は観察 期間を通して安定していた。血漿中濃度の個体間変動 は大きかった。 また, 日本人での曝露 $\left(\mathrm{C}_{\mathrm{max}, \mathrm{ss}}\right.$ および $\left.\mathrm{AUC}_{0-24(\tau, \mathrm{ss})}\right)$ を海外での複数の第 $\mathrm{I}$ 相臨床試験および 第 II 相臨床試験（LUX-Lung 2）のメタアナリシスの結 果と比較したところ, 日本人がん患者の薬物動態特性 は白人がん患者と同様であると考えられた $(9,10)$.

進行固形がん患者 13 例にアファチニブ $40 \mathrm{mg} /$ 日を 空腹時および高脂肪／高カロリー食蛽取後に単回経口 投与した海外での第 I 相臨床試験において, 食事はア ファチニブの曝露量に有意に影響した。高脂肪／高力 ロリー食摂取後におけるアファチニブの $\mathrm{C}_{\text {max }}$ および $\mathrm{AUC}_{0 \sim \infty}$ の幾何平均值は, 空腹時投与と比較してそれ ぞれ 50\%, 39\%低下し, 食後投与ではアファチニブの 
吸収遅延が認められ， $t_{\text {max }}$ 中央值は，空腹時投与の 3.0 時間に比べ 6.9 時間と顕著に延長することが確認され た (11).

3）有効性

（1）EGFR 遺伝子変異を有する EGFR-TKI 未治療例 を対象にした臨床試験

\section{(1)海外第 II 相臨床試験 LUX-Lung 2}

LUX-Lung 2 は, 1 次治療または化学療法後の 2 次治 療でのアファチニブの有効性および安全性を検討する ために，台湾および米国にて非対照非ランダム化探索 的試験として実施された. 本試験は, 腫瘍細胞の $E G F R$ 遺伝子の exon18～21 に活性化変異を有し, かつ 1 種類の細胞傷害性化学療法レジメンに治療不応と なった, あるいは 1 次治療の細胞傷害性化学療法の前 治療歴がない病期 III b またはIV 期の肺腺がん患者 129 例を対象とした。アファチニブの開始用量として, 99 例（1 次治療 38 例，2 次治療 61 例）に $50 \mathrm{mg} /$ 日, 30 例（1 次治療 23 例, 2 次治療 7 例）に $40 \mathrm{mg} /$ 日が 1 日 1 回, 病勢進行（PD）まで連日経口投与された. 有害 事象発生時には, 開始用量が $50 \mathrm{mg} /$ 日の場合は $40 \mathrm{mg} /$ 日または $30 \mathrm{mg} /$ 日に, 開始用量が $40 \mathrm{mg} /$ 日の 場合は $30 \mathrm{mg} /$ 日または $20 \mathrm{mg} /$ 日に減量可能とされた.

その結果, 独立判定委員会の評価において, 主要評 価項目の奏効率 (ORR) は $61.2 \%$ （完全奏効 $(\mathrm{CR})$ : 2 例, 部分奏効 $(\mathrm{PR}): 77$ 例, 79/129 例) であった (12). 副次評価項目の病勢コントロール率 $(\mathrm{DCR}=\mathrm{CR}$, $\mathrm{PR}$ or 不変 $(\mathrm{SD}))$ は $82.2 \%$ (CR : 2 例, $\mathrm{PR}: 77$ 例, SD : 27 例, 106/129 例), PFS 中央值は 10.1 力月, 全生存 期間（OS）中央值は 24.8 カ月であった (12)。また, 1 次治療群 61 例, 2 次治療群 68 例の ORR と PFS 中央值 は，それぞれ $65.6 \%$ と 12.0 力月， $57.4 \%$ と 8.0 力月で
あった(12). また,アファチニブ $50 \mathrm{mg} /$ 日および $40 \mathrm{mg} /$ 日それぞれの開始用量での有効性は同程度で あった (12).

\section{(2)国際共同第 III 相臨床試験 LUX-Lung 3}

国際共同実薬対照非盲検ランダム化第 III 相臨床試験 LUX-Lung 3 は, LUX-Lung 2 の中間解析の結果, EGFR 遺伝子変異を有する NSCLCへのアファチニブの有効 性の Proof of Concept が得られたことを受けて実施さ れた，本試験では，EGFR-TKI を含む化学療法未治療 の $E G F R$ 遺伝子変異陽性（Del 19, L858R など）の病 期 III b またはIV 期の NSCLC 患者 345 例を $2 ： 1$ の比率 で, アファチニブ $40 \mathrm{mg} /$ 日（第 1 サイクル中の忍容性 が高い患者は次サイクルから $50 \mathrm{mg} /$ 日に増量が認め られた), 1 日 1 回空腹時連日経口投与群 230 例と, 標 準化学療法として非扁平上皮がんへの効果が認められ ているペメトレキセド (PEM) $500 \mathrm{mg} / \mathrm{m}^{2}$ 点滴静注 + シスプラチン (CDDP) $75 \mathrm{mg} / \mathrm{m}^{2}$ 点滴静注, 3 週サイ クル投与群 115 例にランダムに割付け, 1 次治療とし てのアファチニブの有効性と安全性が検討された。 ま た, 対象患者 345 例中 83 例が日本人であり, その内訳 は, アファチニブ群が 54 例, PEM + CDDP 群が 29 例 であった。

その結果, 独立判定委員会の評価において, 主要評 価項目の PFS の中央值はアファチニブ群で 11.1 カ月 と, $\mathrm{PEM}+\mathrm{CDDP}$ 群の 6.9 力月に比べ 4.2 力月の有意 な延長が認められた（ハザード比：0.58, 95\%信頼区 間 : 0.43〜0.78, $P<0.001)(13,14)$ (図 3).このうち Del 19 あるいはL858Rを有する 308 例での PFSの中央 值はアファチニブ群で 13.6 カ月と, PEM + CDDP 群 の 6.9 カ月に比べ 6.7 カの延長が認められた（ハ ザード比：0.47，95\% 信頼区間：0.34〜0.65, P<

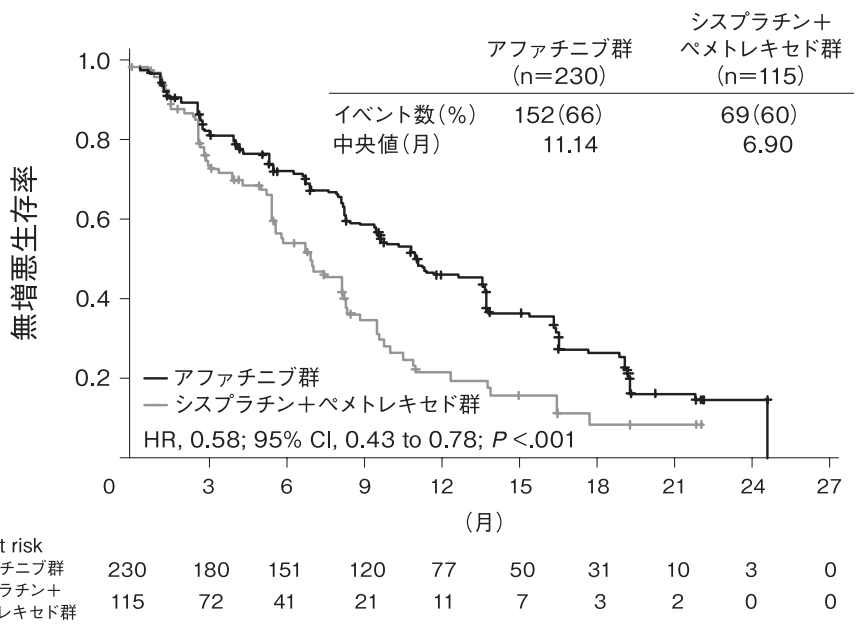

図 3 LUX-Lung 3 における無増悪生存期間（文献 14 より引用・改变） 
表 2 LUX-Lung 3 における EGFR 遺伝子変異の種類別による無増悪生存期間（中央值）

\begin{tabular}{|l|c|c|c|c|}
\hline$E G F R$ 遺伝子変異 & 本剂群 & PEM + CDDP 群 & ハザード比 & $95 \%$ 信頼区間 \\
\hline Del 19 & 13.7 カ月 $(\mathrm{n}=113)$ & 5.6 カ月 $(\mathrm{n}=57)$ & 0.28 & $0.18 \sim 0.44$ \\
\hline L858R & 10.8 カ月 $(\mathrm{n}=91)$ & 8.1 カ月 $(\mathrm{n}=47)$ & 0.73 & $0.46 \sim 1.17$ \\
\hline その他 & 2.8 カ月 $(\mathrm{n}=26)$ & 9.9 カ月 $(\mathrm{n}=11)$ & 1.89 & $0.84 \sim 4.28$ \\
\hline
\end{tabular}

(文献 14 より引用)

0.001) (13).ささらに, EGFR 遺伝子変異の種類別によ るサブグルーブ解析の結果, アファチニブによる PFS 延長効果は Del 19 あるいは L858R を有する患者で高 いことが示された（14）（表2）。ORR およびDCRは， アファチニブ群で $56.1 \%$ および $90.0 \%, \mathrm{PEM}+\mathrm{CDDP}$ 群で $22.6 \%$ および $80.9 \%$ であった（ORR：オッズ比 4.660, $P<0.0001, \quad \mathrm{DCR}$ : オッズ比 2.140, $P=0.0189)$ (15)。OSに関しては, 2013 年 12 月データカットオフ 時点で, アファチニブ群が 28.2 カ月, PEM + CDDP 群 が 28.2 カ月と差は認められなかった(16).

また, アファチニブの有効性は, 日本人のサブグ ループ解析結果においても同様に認められた。独立判 定委員会の評価に押いて, PFSの中央值はアファチニ ブ群で 13.77 カ月と, PEM + CDDP 群の 6.93 カ月に比 べ延長が認められた（ハザード比：0.377，95\%信頼区 間：0.203 0.699, $P=0.0014)(17)$.さらにDel 19 あ るいは L858R を有する患者に限定してみると, アファ チニブ群で 13.77 カ月と, PEM + CDDP 群の 6.93 カ月 に比べ延長が認められた (ハザード比 : 0.276, 95\%信 頼区間 : 0.148 0.517, $P<0.0001)(18)$.

さらに，試験開始後，21 日ごとに EORTC QLQ-C30, QLQ-LC13 質問票を用いて肺がん関連症状と健康に 関するQOLを評価したところ，アファチニブ群は $\mathrm{PEM}+\mathrm{CDDP}$ 群に比べ, 呼吸困難の改善 (64\% vs. $50 \%, P=0.010)$ と, 咳嗽 $(P=0.244)$ と疼痛 $(P=$ 0.051）の改善傾向が涊められた (19). 咳嗽, 呼吸困難 に関して，アファチニブ群は PEM + CDDP 群に比べ, 症状が増悪するまでの期間も延長した (19).

\section{(3)国際共同第 III 相臨床試験 LUX-Lung 6}

LUX-Lung 3 で示されたアファチニブの有効性は, 中国, 韓国, 夕イに扔いて実施された実薬対照非盲検 ランダム化第 III 相臨床試験 LUX-Lung 6 においても確 認されている. LUX-Lung 6 では, EGFR-TKIを含む化 学療法未治療の $E G F R$ 遺伝子変異を有する進行 NSCLC 患者 364 例を対象に，アファチニブ $40 \mathrm{mg} /$ 日， 1 日 1 回空腹時連日経口投与群とゲムシタビン (GEM) $1000 \mathrm{mg} / \mathrm{m}^{2}$ 点滴静注 + CDDP $75 \mathrm{mg} / \mathrm{m}^{2}$ 点滴静注群 の有効性と安全性が検討された，その結果，独立判定 委員会の評価に抢いて, 主要評価項目である PFSは,
アファチニブ群で 11.0 カ月と, $\mathrm{GEM}+\mathrm{CDDP}$ 群の 5.6 カ月に比べ有意な延長が認められた（ハザード 比：0.28, 95\%信頼区間 : 0.20 0.39, $P<0.0001)(20)$. アファチニブ群, GEM + CDDP 群それぞれにおける ORRは $66.9 \%$ と $23.0 \%(P<0.0001), D C R$ は $92.6 \%$ と $76.2 \%(P<0.0001)$ であった $(20)$.

また, 試験開始後, 21 日ごとに EORTC QLQ-C30, QLQ-LC13 質問票を用いて肺がん関連症状と健康に 関するQOLを評価したところ, アファチニブ群は $\mathrm{GEM}+\mathrm{CDDP}$ 群に比べ, 咳嗽 $(P<0.0001)$, 呼吸困難 $(P<0.0001)$, 疼痛 $(P=0.003)$ いずれも改善がみられ た (20).ささらに,アファチニブ群は $\mathrm{GEM}+\mathrm{CDDP}$ 群 に比べて, 咳嗽, 呼吸困難, 疼痛いずれにおいても増悪 までの期間が長く, 症状スコアも低下がみられた $(20)$.

以上, LUX-Lung 3 および LUX-Lung 6 の結果から, ア ファチニブは, $E G F R$ 遺伝子変異を有する進行 NSCLC 患者への 1 次治療に扔いて, 標準的化学療法に対する 優越性が示された。

\section{(2) 可逆的 EGFR-TKI 既治療例を対象にした臨床試験 (1)海外第 II b/ III 相臨床試験 LUX-Lung 1}

LUX-Lung 1 は，可逆的EGFR-TKI 既治療例を対象に アファチニブ+最善の支持療法（BSC）群とプラセ ボ+BSC 群の有効性と安全性を比較検討した二重盲 検ランダム化プラセボ対照試験である。本試験では, 1 種類または 2 種類の細胞傷害性化学療法（1 種類は プラチナ製剤ベース）拉よび可逆的 EGFR-TKI である ゲフィチニブまたはエルロチニブによる 12 週間以上 の治療を受け, 可逆的 EGFR-TKIにより病勢コント ロールが得られたものの最終的に疾患が進行した病期 III b 期またはIV期の進行 NSCLC 患者 585 例を 2：1の 比率で, アファチニブ $50 \mathrm{mg} /$ 日, 1 日 1 回空腹時連日 経口投与 + BSC 群 390 例と, プラセボ + BSC 群 195 例 にランダムに割付けて実施された。

その結果, 独立判定委員会の評価において, 主要評 価項目である OS の主解析時点での中央值は, アファ チニブ+ BSC 群で 10.8 カ, プラセボ + BSC 群で 12.0 カ月と両群間に有意差は認められなかった (21). PFS については, アファチニブ+ BSC 群が 3.3 カ月と, プラセボ+ BSC 群の 1.1 カ月に比べ延長が認められた 
(ハザード比 : $0.38 ， 95 \%$ 信頼区間 : $0.31 \sim 0.48, \quad P<$ $0.0001)(21)$.

\section{(2) 国内第 I / I 相臨床試験 LUX-Lung 4 の第 II 相パート}

LUX-Lung 4 の第 II 相パートは, 1 種類または 2 種類 の細胞傷害性化学療法 (1 種類はプラチナ製郕ベース) による治療を受け, 可逆的 EGFR-TKI であるゲフィチ ニブあるいはエルロチニブを 12 週間以上投与したに もかかわらず，画像的に増悪が確認された治療不応の NSCLC 患者（病期 II b またはIV期）を対象に実施され た非盲検非対照の用量反応探索的試験で, LUX-Lung 1 のブリッジング試験として実施された.

アファチニブ $50 \mathrm{mg}$ /日を 1 日 1 回連日経口投与し, 有効性㧍よび安全性が検討された結果, 独立判定委員 会の評価に抒いて, 主要評価項目の ORR は $8.2 \%$, DCRは $65.6 \%$ あった. また, 副次評価項目のPFS中 央值は 4.4 力月, OS 中央值は 19.0 力月であった (22).

\section{4）安全性}

アファチニブの投与に伴い発現する主な有害事象と して, 下痢, 発疹/ざ瘡, 口内炎, 爪の異常が多く認 められている. 日本人患者に対し化学療法と比較した アファチニブの臨床的有効性および安全性は, LUXLung 3 で確認されている. LUX-Lung 3 のアファチニ ブ投与群では, アファチニブとの因果関係が否定でき ない有害事象として, 下痢 $(95.2 \%)$, 発疹 /ざ瘡 (89.1\%), 口内炎 $(72.1 \%)$, 爪の異常 $(61.1 \%)$ が認め ら れ, National Cancer Institute Common Terminology Criteria for Adverse Events（NCI-CTCAE）グレード 3 以上の発現率は, 下㾥 $(14.4 \%)$, 発疹/ざ瘡 $(16.2 \%)$, 口内炎 (8.7\%), 爪の異常 (11.8\%) であった (23).

LUX-Lung 3 では, 症状が持続的または忍容できな い有害事象が認められた場合にアファチニブを休薬し， 症状が回復した後に $10 \mathrm{mg}$ ずつ減量する減量規定が 設定された，本試験において，アファチニブの減量に 至った有害事象で高頻度に認められたものは, 下痢 (19.7\%), 発疹/ざ瘡 $(19.2 \%)$, 爪の異常 $(13.5 \%)$, 口内炎 $(10.0 \%)$ であり，アファチニブ投与群のうち, $52.4 \%$ の患者が $40 \mathrm{mg}$ から $30 \mathrm{mg}$ に減量し， 17.5\%の 患者が $20 \mathrm{mg}$ に減量した。一方, アファチニブ投与群 の $70.7 \%$ の患者は 6 力月間投与を継続することができ， $44.1 \%$ の患者は 12 力月以上投与を継続することがで きた。 アファチニブとの因果関係が否定できない投与 中止に至った有害事象の発現率は $7.9 \%$ であった(24).

以上から, アファチニブ投与による有害事象は, 減 量基準に基づく休薬／減量, および適切で積極的な支 持療法により管理が可能であると考えられた。実地臨 床においては, アファチニブの薬物動態が個体間変動
の大きいことを考虑し, 投与開始初期には有害事象の 頻度や重症度を観察するなど注意深い管理を行い, 有 害事象の発現に応じて至適用量まで用量を調整するた めに休薬／減量を行う必要があるほか, 特に下痢, 発 疹／ざ瘡, 口内炎, 爪の異常の発現に注意し, 支持療 法の早期開始などの積極的な管理を行うことが重要で ある。

\section{4. 今後の展望}

LUX-Lung 3 およびLUX-Lung 6 の結果から, EGFR 遺伝子変異陽性の進行・再発 NSCLC に対する 1 次治 療に抢いて，アファチニブの有効性が示された。現在, アファチニブと可逆的 EGFR-TKI であるゲフィチニブ, エルロチニブとの有効性・安全性に関する比較試験が 進められている. 第 II b 相試験 LUX-Lung 7 では, 1 次 治療におけるアファチニブとゲフィチニブの効果につ いて比較検討されている(25)。 また, 第 III 相試験 LUX-Lung 8 では, プラチナ製剤ベースの化学療法が 不応となった肺扁平上皮がんに対して，2次治療とし てのアファチニブとエルロチニブの効果が比較検討さ れている(26).

$E G F R$ 遺伝子変異陽性 NSCLC 患者に対する EGFRTKI では，耐性の獲得・発現が指摘され，その克服に 向けた治療戦略を確立することが今後の課題となって いる，そのひとつの方法として，増悪後の継続投与が 考えられている. 国際多施設共同オープンラベルラン ダム化臨床試験 LUX-Lung 5 では, エルロチニブ／ゲ フィチニブおよび化学療法による治療が無効になり,

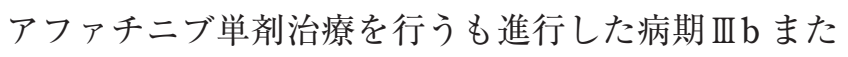
はIV 期の EGFR 遺伝子変異陽性 NSCLC 患者を対象に, アファチニブ+パクリタキセル（週 1 回投与法）と化 学療法の効果が比較検討されている $(27)$.

また，肺がん以外では，プラチナ製剤による化学療 法後に進行した再発・転移頭頸部扁平上皮がんを対象 にした二つの第 III 相試験（LUX-Head\&Neck 1, LUXHead\&Neck 3）が異なる地域で実施されているほか, 頭頸部扁平上皮がんにおける化学放射線療法後の補助 療法としての有効性を検討する二つの第 III 相試験 (LUX-Head\&Neck 2, LUX-Head\&Neck 4) が実施され ている(28-31).

著者の利益相反 : 高橋 希, 鈴木 忍, 酒井兼司, 東 久弥 (日本ベーリンガーインゲルハイム株式会社). 


\section{文}

\section{献}

1) Mitsudomi T, et al. Lancet Oncol. 2010;11:121-128.

2) Maemondo M, et al. N Engl J Med. 2010;362:2380-2388.

3) Zhou C, et al. Lancet Oncol. 2011;12:735-742.

4) Rosell R, et al. Lancet Oncol. 2012;13:239-246.

5) 肺癌診療ガイドライン IV 期非小細胞肺癌の 1 次治療. 日本 肺癌学会 編. http://www.haigan.gr.jp/modules/guideline

6) ジオトリフ錠医薬品インタビューフォーム. 日本ベーリン ガーインゲルハイム株式会社. p. 29-36.

7）ジオトリフ錠医薬品インタビューフォーム. 日本ベーリン ガーインゲルハイム株式会社. p. 3-4.

8) Li D, et al. Oncogene. 2008;27:4702-4711.

9) Yap TA, et al. J Clin Oncol. 2010;28:3965-3972.

10) Murakami H, et al. Cancer Chemother Pharmacol. 2012;69:891899

11）ジオトリフ錠医薬品インタビューフォーム. 日本ベーリン ガーインゲルハイム株式会社. p. 37-50.

12) Yang JC, et al. Lancet Oncol. 2012;13:539-548.

13) Sequist LV, et al. J Clin Oncol. 2013;31:3327-3334.

14）ジオトリフ錠医薬品インタビューフォーム. 日本ベーリン ガーインゲルハイム株式会社. p. 10-28.

15）アファチニブマレイン酸塩 CTD 2.7.3 臨床的有効性. 日本 ベーリンガーインゲルハイム株式会社. p. 119-123. http:// www.info.pmda.go.jp/shinyaku/P201300171/index.html

16) Yang JC, et al. J Clin Oncol. 2014;32 Suppl 5:8004.

17）アファチニブマレイン酸塩 CTD 2.7.3 臨床的有効性. 日本 ベーリンガーインゲルハイム株式会社. p. 105-112. http://
www.info.pmda.go.jp/shinyaku/P201300171/index.html

18）アファチニブマレイン酸塩 CTD 2.7.3 臨床的有効性. 日本 ベーリンガーインゲルハイム株式会社. p. 175-179. http:// www.info.pmda.go.jp/shinyaku/P201300171/index.html

19) Yang JC. J Clin Oncol. 2013;31:3342-3350.

20) Wu YL, et al. Lancet Oncol. 2014;15:213-222.

21) Miller VA, et al. Lancet Oncol. 2012;13:528-538.

22) Katakami N, et al. J Clin Oncol. 2013;31:3335-3341.

23）アファチニブマレイン酸塩 CTD 2.7.6 個々の試験のまとめ. 日本ベーリンガーインゲルハイム株式会社. p. 312-314. http://www.info.pmda.go.jp/shinyaku/P201300171/index.html

24）アファチニブマレイン酸塩 CTD 2.7.4 臨床的安全性. 日本 ベーリンガーインゲルハイム株式会社. p. 3-9. http://www. info.pmda.go.jp/shinyaku/P201300171/index.html

25) LUX-Lung 7. ClinicalTrials.gov. http://clinicaltrials.gov/ct2/show/ NCT01466660

26) LUX-Lung 8. ClinicalTrials.gov. http://clinicaltrials.gov/ct2/show/ NCT01523587

27) LUX-Lung 5. ClinicalTrials.gov. http://clinicaltrials.gov/ct2/show/ NCT01085136

28) LUX-Head\&Neck 1. ClinicalTrials.gov. http://clinicaltrials.gov/ ct $2 /$ show/NCT01345682

29) LUX-Head\&Neck 2. ClinicalTrials.gov. http://clinicaltrials.gov/ ct2/show/NCT01345669

30) LUX-Head\&Neck 3. ClinicalTrials.gov. http://clinicaltrials.gov/ ct2/show/NCT01856478

31) LUX-Head\&Neck 4. ClinicalTrials.gov. http://clinicaltrials.gov/ ct $2 /$ show/NCT02131155 